For citation: Ruzhanskaya, L. S., Lukyanov, S. A. \& Alaev, G. A. (2018). Country Effects on Managerial Practices in Transportation Area: Evidence from Russia and Germany. Ekonomika regiona [Economy of Region], 14(2), 530-535 doi 10.17059/2018-2-15

UDC 005

JEL: L21, M16

\author{
L. S. Ruzhanskaya ${ }^{\text {b) }}$, S. A. Lukyanov ${ }^{a, b, c)}$, G. A. Alaev ${ }^{\text {b) }}$ \\ a) State University of Management (Moscow, Russian Federation: e-mail: s.kukyanov@mail.ru) \\ b) Ural Federal University (Ekaterinburg, Russian Federation) \\ c) St. Petersburg State University (St. Petersburg, Russian Federation)
}

\title{
COUNTRY EFFECTS ON MANAGERIAL PRACTICES IN TRANSPORTATION AREA: EVIDENCE FROM RUSSIA AND GERMANY ${ }^{1}$
}

The competitiveness of individual companies is related not only to their own characteristics, but also to the institutional and economic characteristics of the home countries of these companies. How the business environments of countries affect the results of applying management practices in different companies is a complex research issue, as managerial practices have many characteristics. Nevertheless, Russian enterprises have to use new technologies to increase competitiveness in the world market. We analysed both the sector of transportation where geographic closeness is a key indicator of competition, and transportation facilities where incremental costs and savings can be implemented to build variables of the market structures. The research sample includes 210 specialized logistic firms with variation of ownership structure and collateral agreements. We have examined firms in two markets: Russian and German ones. The analysis is based on the data from 7 Russian regions, and 6 German federal states. We have found that the quality of managerial practices - estimated by using a new survey instrument - is strongly linked with commercial ratios such as a rate of fail to deliver and a rate of consumer satisfaction. A high level of competitiveness is demonstrated by a greater number of companies in the same region. We have found that this is positively correlated with increased quality of managerial capabilities. This correlation is reinforced when we quantify the number of local firms with local logistic infrastructure. This paper reveals that the increasing the effectiveness of managerial practices are due to the characteristics of the country of origin. The results allow to develop recommendations for policy-makers to improve the business environment.

Keywords: transfer of managerial technology, managerial practices, cross-country analysis, transportation, efficiency of resources, project management, logistics infrastructure

\section{Introduction}

For the past several years, management researchers have thoroughly estimated outstanding deviations in performance between firms within countries and also across countries. The questions as to why this deviation exists, where it founded from, and how it influences economic development have populated scientific journals ever since. One factor long thought to be linked to these deviations is the quality of managerial capabilities introduced at the institutional level. The management of an institution can have a number of different issues, and, thus, it becomes clear that deviations in the point of view of how and what managerial capabilities to introduce will arise.

Understanding the instance of managerial capabilities and their influence on firm performance is a crucial stage bringing the understanding of the development of a sector as well as the contribu-

${ }^{1}$ ( ) Ruzhanskaya, L. S., Lukyanov, S. A. \& Alaev, G. A. Text. 2018. tion to business development as a whole. However, because of absence of relative evidence and data, especially emerging markets, it is only a few working papers related to this interesting field.

\section{Theory}

The concept of management technologies appeared in the 1960s. It was considered as information and tools for its storage J. Woodward [24], as activity and knowledge about cause-and-effect relations J. Thompson [21] and as a variability of C. Perrow's search process [18]. A new surge of interest in the topic occurred in the 1970s in connection with the transfer of technology. First of all, the term «management know-how» appeared as «various managerial practices, principles, and techniques used by managers in the United States and Western Europe to perform five main functions: planning, organization, recruitment, management and control» [16, p. 54]. During this period, most researchers considered managerial 
know-how as an element of overall economic development [25]. In addition, terms such as organizational technology [23] and administrative technology are widely used. The next step in the development of the concept of management technologies was the introduction of the term «transfer of knowledge», which is defined as the process of interaction through which a recipient (organization, unit, group, personality) receives the experience and knowledge of the donor [4]. Thus, the field of research was expanded in the search for the sources of competitiveness of a company.

The resource concept formulated by B. Wernerfelt [22] found that the source of competitive advantages of the company is the uniqueness of its resources. The development of specific resources and practices of the company allows it to retain a competitive advantage and the ability to make a profit. At the same time, the firm must create value important for the consumer $[6$, 19]. The combination of specific resources and dynamic capabilities of the company is a key element in obtaining a competitive advantage [12]. The resource concept sees the management of the company as a source of economic profit creation. This thesis was confirmed by the empirical work of R. Ramelt «How much does industry matter?» [20]. There he found that the differences in profits at the inter-firm level exceed the inter-sectoral level by seven times. Thus, the effect of introducing a new management practice depends on how this practice will serve to create a specific resource or dynamic ability of the company, which will allow it to create value that is important for the consumer.

The cross-country studies of management practices concluded that firms in low-and-middleincome countries, as well as countries with economies in transition, have significantly lower levels of management practices and specific resources than companies from developed countries [7, 17].

Recent studies found that managerial capabilities - expressed in form of three key factors: monitoring, targets, and incentives - are clearly related to firm and national performance $[1,2$, 13]. In short view, these working papers find that, firms which have better managerial capabilities, as a result, have better commercial and production outcomes (outcomes were measured by different rations e.g. net income, gear ratio, sales per employee); a high level of managerial capabilities lead to higher sales per employee performance in retail sector; $s$ high level of managerial capabilities in public healthcare have lower level of heart attack mortality rates; a high level of managerial capabilities in public schools lead to better average score per student $[10,11]$. A recent qualitative study on 28 Indian textile plants performed the analysis of related crosslinks and take attention to a visible correlation between managerial capabilities and production level [10]. Managerial consulting activities were provided to a population of casually selected factories to help them apply managerial capabilities and compared their financial and production outcomes to a different casual chosen dataset of controls $[8,17]$. This study has shown that application of good managerial capabilities for targets, monitoring and incentives was intensively effective, and in short run perspective can increase the level of production of $18 \%$.

Another general outcome to this working paper is that manufacturing plant in countries with low and middle income have, on average, much downscale managerial capabilities rather than plants in countries with high income [3, 17]. Notwithstanding, the presence of several companies with world-class managerial capabilities in countries with low and middle income, the low average quality of managerial capabilities in these countries seems to be due to a large set of firms with worse managerial capabilities. Such firms with bad management practices usually work without fundamental types of monitoring as well as targets and incentive mechanisms common for the firms from developed countries. Therefore, it leads to the low level of production. $[5,11]$.

\section{Data and Methods}

To evaluate the managerial practices that managers used during their day-to-day duties, we used the methodology proposed in Nick Bloom and John Van Reenen's working paper [11]. We introduced their management estimation tool to the transportation public sector setting, giving attention to information from the managerial literature $[8,10]$. We accumulated qualitative and quantitative datasets related to managerial practices for 210 firms of transportation and logistics sector in Russia and Germany. For each organization, we involved three dimensions of management practices: one related to monitoring and incentives, one broadly related to the autonomy, and one concerned to other effects of managerial practices.

To assume our theoretical implications related to the efficiency of implementation of good managerial practices in different countries, we use carriage management in Russia and Germany. We assume that Russia is estimated as transitional economy and Germany is estimated as a developed economy.

Transport and communication had $7 \%$ share of GDP in the Russian economy in 2015 (based on Rosstat data). In the same time, transport also 
Table 1

Carriage operations structure: a comparative analysis

\begin{tabular}{|c|c|c|c|c|c|}
\hline \multirow[b]{2}{*}{ № } & \multirow{2}{*}{$\begin{array}{l}\text { Type of } \\
\text { transport }\end{array}$} & \multicolumn{2}{|c|}{ Russia } & \multicolumn{2}{|c|}{ Germany } \\
\hline & & $\begin{array}{l}\text { Volume, } \\
\text { th. tons }\end{array}$ & Share \% & $\begin{array}{l}\text { Volume, } \\
\text { th. tons }\end{array}$ & $\begin{array}{c}\text { Share, } \\
\%\end{array}$ \\
\hline 1 & Railroad & 1217948 & 19,05 & 365003 & 8,29 \\
\hline 2 & Trucks & 5040594 & 78,80 & 3506500 & 79,6 \\
\hline 3 & $\begin{array}{l}\text { River } \\
\text { shipping }\end{array}$ & 118415 & 1,85 & 228489 & 5,19 \\
\hline 4 & $\begin{array}{l}\text { Marine } \\
\text { shipping }\end{array}$ & 18283 & 0,28 & 300120 & 6,82 \\
\hline 5 & $\begin{array}{l}\text { Aviation } \\
\text { freight }\end{array}$ & 1064 & 0,02 & 4396 & 0,1 \\
\hline 6 & TOTAL & 6396306 & 100 & 4404508 & 100 \\
\hline
\end{tabular}

Source: authors, based on Rosstat and FSGS databases.

had a significant segment in the macroeconomic system (15\% of GDP, based on Federal Statistical Government Service database) (Table 1).

We do not use in our analysis pipeline transportation because it is used for specific purposes such as transportation of liquid gas or crude oil. Thus, there is a lot of technological circumstances. A second reason complies difference in a type of business structures - such communications are owned and used by large conglomerates such as E.ON in Germany or Transneft in Russia. That is why this type of transport is not appropriate for our analysis.

\section{Qualitative Data}

The shell for the econometric regression is obtained from different implications. The first is the management overlook prepared by the Department of Management at the Ural Federal University and the Faculty of Economics and Business Administration at the European University Viadrina in Frankfurt am Oder. It includes 18 responses from which managerial capabilities source is calculated plus additional data regarding the process of the interviewing and specialties of the organizations. This is crosschecked by independent datasets from the State Ministry of Transport, Russian-German Trade Chamber, and other government structures, which represent data on the measurement of qualitative and quantitative characteristics and access estimation of firm's characteristics. Our working database is working on 510 carriage operations from 210 organizations. The geographical proximity of research includes 4 federal states and 2 cities in Germany and 5 states in Russian Federation.

The substance of the questionnaire is consist of 18 points, which have been unified in the following four groups: targets (5 ranked questions), incentives management (5 ranked questions), monitoring (4 ranked questions), targets (4 ranked questions). For each of interviewee responses, the interviewer reports a specific index between 1 and 8 , a higher value indicating a higher outcome in the chosen subcategory.

To try to avoid responses with biases, we used a blinded interviewing approach. The first stage of this was that the interview procedure was performed by telephone or Skype without supplementary data for managers in advance that they would be evaluated. The second stage included the sending of the questionnaire by email or fax with 18 questions. Moreover, these questions catch current firms' managerial practices and examples, with the additional questions until the interviewer can make an appropriate estimation of the routine managerial capabilities related to these cases. The questions correlate in the following manner to these clusters. Autonomy: 1-4, Monitoring: 5-8, Targets: 8-12, Incentives management: 13-18. Conducting of the survey with managers was supported by an official letter from the State Ministry of Transport or Russian-German Trade Chamber, and the name of the Ural Federal University. Interviewing process held under an hour. We interviewed up to three persons in every organization - a general manager, operational manager and business development manager. The response rate of return was unlinked with variables such as performance outcomes and other organizational matters such as headcount, country factor etc.

\section{Performance Survey Data}

Measurement of productivity is quite difficult in service organizations, especially in the transportation sector, so regulators and researchers, as a rule, should perform a wide range of calculations [15]. The commercial outcomes we use are the stage of completion rate of carriage operation.

\section{Other Controls}

First, we control for a mix of operations (case mixing) by controlling for the stage of completion. We also control for the total number of project implemented within an organization. That affects their quality and is connected with economy scales: developed one (Germany) or developing one (Russia).

Second, we estimate effectiveness for resources of the firms, which are all related to logistics infrastructure. The purchasers of infrastructure subjects such as warehouses, roads estimate a defined geographical proximity and measures allocation of the resources on the approach, which related to the evaluation of firm's outcomes. This system is invented to prevent the use of resources allo- 
cation for supporting bad managerial capabilities. Moreover, we are concerned to control the influence of capabilities as they may impact on both commercial results and the options of managerial capabilities. We also seek to ensure that our variables will not be defined by resources connected to the geographic proximity. This methodology is consistent with the principles of research using panel data [14].

\section{Empirical Model}

Our empirical model, as a survey unit uses $i$-operation on delivery of $j$ type in $n$ organization. We evaluate the following OLS, where $\gamma_{i j n}$ complement to the carriage operation rate of completion, or the quality assessment of the carriage operation, as described in Table 1, and the three main variables of managerial practice are the $C S_{\text {autonomy' }}$ $C S_{\text {incentives }}$ and $C S_{\text {other }}$ indicators described below in equation (1).

Because of many organizations observe realization of the similar type of carriage operations $\mathrm{j}$, we estimate variable for fixed effects of the carriage operation $\alpha$ in our basic model (1). In basic equation (1), we assume that within carriage operation, complexity/simplicity characteristic and managerial characteristics are non-similar for each carriage operation:

$$
\begin{aligned}
\alpha_{i j n}= & \alpha_{i j n} C S_{\text {autonomy }}+\alpha_{i j n} C S_{\text {incentives }}+ \\
& +\alpha_{i j n} C S_{\text {other }}+P C_{i j n}+O C_{n}
\end{aligned}
$$

To provide availability for interpretation of the evaluated crosslinks related to management practices and carriage operation completion rates, we need to review three observed assumptions: (i) projects are distributed in a random way within organizations based on their managerial capabilities; (ii) unobserved firm characteristics related to managerial capabilities are also derived from the indecies of project completion; (iii) managerial capabilities are heterogenious and tailored by local management characteristics or project results. As follows, we use our results to describe crosslinks between various forms of managerial capabilities and project completion rates as described in Table 1.

$P C_{i j n}$ includes operation data such as complexity or simplicity, budget rate and whether the operation is on continuance basis or not. OCn includes the log headcount, the quantity of university graduated managers.

The testing of correlation of Monitoring and Targets dimensions is not provided sustainable statistical evidence in contradistinction to Autonomy and Incentives dimensions. Developed system of procedures and reglamentation of codes
Table 2

Correlation between accumulated carriage stage of completion and management practices within firms:

Part A. Russia

\begin{tabular}{|l|c|c|c|c|}
\hline \multirow{2}{*}{$\begin{array}{c}\text { Indepen- } \\
\text { dent } \\
\text { variables }\end{array}$} & \multicolumn{4}{|c|}{ The rate of carriage operation completion } \\
\cline { 2 - 5 } & Failed & $\begin{array}{c}\text { Less than } \\
\mathbf{5 0} \%\end{array}$ & $\begin{array}{c}\text { More than } \\
\mathbf{5 0} \%\end{array}$ & Successful \\
\hline Autonomy & 0.12 & 0.21 & 0.22 & 0.19 \\
\hline Incentives & -0.017 & -0.11 & -0.11 & -0.14 \\
\hline Other & 0.10 & 0.05 & 0.05 & 0.08 \\
\hline PC & \multicolumn{5}{|c|}{ unobserved } \\
\hline OC & \multicolumn{5}{|c|}{} \\
\hline
\end{tabular}

Part B. Germany

\begin{tabular}{|l|c|c|c|c|}
\hline \multirow{2}{*}{$\begin{array}{c}\text { Indepen- } \\
\text { dent } \\
\text { variables }\end{array}$} & \multicolumn{4}{|c|}{ The rate of carriage operation completion } \\
\cline { 2 - 5 } & Failed & $\begin{array}{c}\text { Less than } \\
\mathbf{5 0} \%\end{array}$ & $\begin{array}{c}\text { More } \\
\text { than } \mathbf{5 0} \%\end{array}$ & Successful \\
\hline Autonomy & 0.1 & 0.18 & 0.17 & 0.18 \\
\hline Incentives & -0.06 & -0.11 & -0.11 & -0.16 \\
\hline Other & 0.10 & 0.05 & 0.05 & 0.08 \\
\hline PC & \multicolumn{5}{|c|}{ unobserved } \\
\hline OC & \multicolumn{5}{|c|}{} \\
\hline
\end{tabular}

Source: performed by authors.

of conduct, sustainable business processes on the middle-management level, operating on the level on day-to-day delivery operations related to low level of Autonomy. Effective labor contracts based on key performance indicators and remuneration based on characteristics such as carriage operation completion rate, the rate of Client satisfaction are related to high values of Incentives dimension.

In Table 2, we represent a chi-square statistics for each stage of project completion. We can assume that difference between the influence of managerial capabilities for carriage operations of German and Russian firms on the stage of completion could be various depending on failure/ success of each operation. From the other side, we should asses a country factor on the weight of each independent variable on the carriage operation stage. Furthermore, we can split high influence of one managerial practice in Russia (Part A) and Germany (Part B) (See Table 2).

As we can see from Table 2, the level of correlation between management practice dimensions and s stage of completion is quite similar for Russia and Germany. Moreover, characteristics of noise variables and project controls are unobserved in the model. By using the method of approximation, we build up a spit chart of coefficients of Autonomy and Incentives on the stage of carriage operation completion (Figure 1):

Notes: We assume a carriage operation rate of completion of $\mathrm{p} \%$ and then consider all potential outcomes from $1 \%$ to $100 \%$ accrued of $1 \%$. 


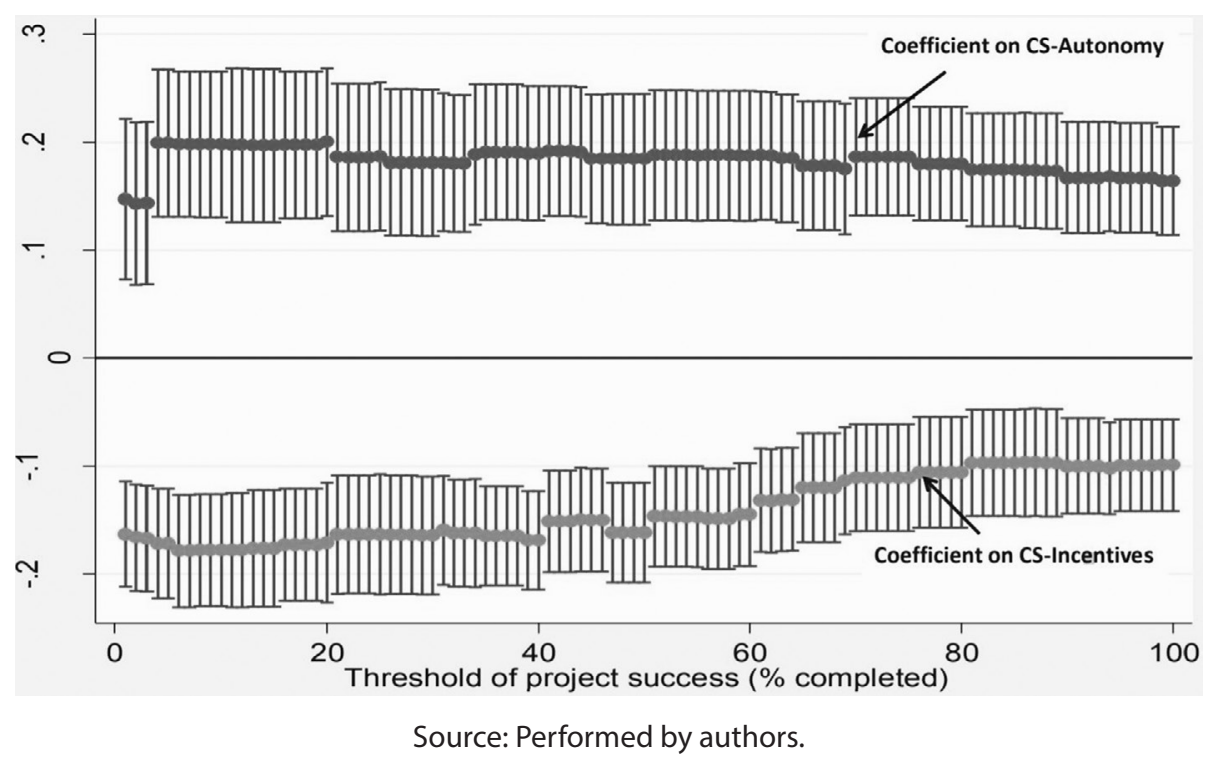

Fig. 1. Approximation of coefficients of Indexes at different levels of the stage of completion

\section{Results}

Based on our results, we can assume, that transportation organizations do not pay attention to managerial practices of their business. The different types of operations have different types of characteristics. Thus, there is no universal toolkit of managerial practices fit with the same quality to a wide range of transport operations. Other explanation for these phenomena is related to the low quality of project management, that key stakeholders do not measure project management approaches to day-to-day routine operations. That is why measurement of quality of such operations seems difficult. Moreover, as stated in [9], a worth level of managerial practices could be explaned by the fact, that the cost of management quality improvement is higher than potential returns from these actions. In fact, this is especially applicable for Russia, a country with a transitional economy, low level of competition and high transaction costs, where the mechanism of the market economy is still gather momentum.

\section{Conclusions}

We can conclude that the process of transfer of managerial technologies has a number of key differences from the transfer of production or product technologies. In general, the transfer process itself carries certain risks, since the costs incurred by the misuse of transferred technologies may be higher than the expected profit. At the same time, cross-cultural interaction is an additional risk factor in the transfer of management technologies. According to the survey, the factor of national culture is not always taken into account. Most authors focus their attention on intra-firm and inter-firm transfer, using cognitive approaches to the study. There is a clear lack of research on the practical results of the transfer, as exemplified by the relocation of production units, mergers and acquisitions and the interaction of transnational corporations. The least studied area is the transfer of management technologies in the field of intangible production.

\section{References}

1. Acemoglu, D. (2005). Politics and Economics in Weak and Strong States. Journal of Monetary Economics, 52, 1199226. doi: 10.1016/j.jmoneco.2005.05.001.

2. Acemoglu, D. (2007). Technology, Information and the Decentralization of the Firm. Quarterly Journal of Economics, 122, 1759-99. doi: 10.3386/w12206.

3. Aghion, P. \& Tirole, J. (1997). Real a Formal Authority in Organizations. Journal of Political Economy, 105, 1-29. doi: 10.4236/jss.2016.41010.

4. Argote, L. \& Ingram, P. (2000). Knowledge transfer: a basis for competitive advantage in firms. Organizational behavior and Human Decision Process, 82, 150-169. doi:10.1006/obhd.2000.2893.

5. Baker G.P. (2002). Distortion and Risk in Optimal Incentive Contracts. Journal of Human Resources, 37, 728-751.

6. Barney, J. B. (1991). Firm resource and sustainable competitive advantage. Journal of Management, 17, 99-120.

7. Black, S. \& Lynch, L. (2001). How to Compete: The Impact of Workplace Practices and Information Technology on Productivity. Review of Economics and Statistics, 88, 434-45. doi: 10.3386/w6120.

8. Bloom, N., Eifert, B., Mahajan, A. \& Mckenzie, D. (2013). Does Management Matter: Evidence from India. Quarterly Journal of Economics, 128, 1-51. doi: 10.3386/w16658. 
9. Bloom, N, Proper, C., Seiler, S. \& Van Reenen, J. (2014) The Impact of Competition on Management Practices in Public Hospitals. Review of Economic Studies, 73, 191-220. doi: 10.1093/restud/rdu045.

10. Bloom, N., Sadun, R. \& Van Reenen, J. (2012). The Organization of Firms Across Countries. Quarterly Journal of Economics, 127(4), 1663-1705. doi: 10.1093/qje/qje029.

11. Bloom, N. \& Van Reenen, J. (2010) New Approaches to Surveying Organizations. American Economic Review, 100, 105-109. doi: 10.1257/aer.100.2.105.

12. Eisenhardt, K. M. \& Martin, J. A. (2000). Dynamic capabilities: What are they? Strategic Management Journal, 21(10/11), 1105-1121. doi: 10.12691/jfe-2-5-9.

13. Fehr, E., Herz, H. \& Wilkening, T. (2013). The Lure of Authority: Motivation and Incentive Effects of Power. American Economic Review, 103, 1325-59. doi: 10.1257/aer.103.4.1325.

14. Huselid, M. A. \& Becker, B. E. (1996). Methodological issues in cross-sectional and panel estimates of the human resource-firm performance. Industrial Relations, 35(3), 400-422. doi: 10.2307/256712.

15. Lichtenberg, F. R. \& Siegel, D. (1990). The effects of leveraged buyouts on productivity and related aspects of firm behavior. Journal of Financial Economics, 27(1), 165-194. doi:10.1016/0304-405X(90)90025-U.

16. Negandhi, A. R. (1968). Advanced management know-how in underdeveloped countries. California management review, 10(3), 53-62. doi: 10.2307/41164117.

17. Nickell, S. (1996). Competition and Corporate Performance. Journal of Political Economy, 4, 724-746. doi: 10.1086/262040.

18. Perrow, C. (1967). A Framework for the comparative analysis of organization. American Sociological Review, 2(6), 654-866. doi: 10.2307/2091811.

19. Peteraf, M. A. (1993). The cornerstones of competitive advantage: A resource-based view. Strategic Management Journal, 14, 179-191. doi: 10.1002/smj.4250140303.

20. Rumelt, R. P. (1991). How much does industry matter? Strategic Management Journal, 12, 167-185.

21. Thompson, J. D. (1967). Organizations in Action. New York, 83.

22. Wernerfelt, B. (1984). A resource-based view of the firm: ten years after. Strategic Management Journal, 16, $171-174$. doi: $10.12691 /$ jfe-2-5-9.

23. Westney, D. E. (1989). The international transfer of organizational technologies. International trade journal, 4(1), 69-91.

24. Woodward, J. (1965). Industrial organization: Theory and Practice. New-York, 145-149.

25. Yavas, U. \& Cavusgil, T. (1989). Management Know-How Transfer for developing countries: efficiency of specialized training courses. Management International Review, 29(3), 72-80.

\section{Authors}

Liudmila Stanislavovna Ruzhanskaya - Doctor of Economics, Professor, Head of the Academic Department of International Economics and Management, Graduate School of Economics and Management, Ural Federal University, Scopus Author ID 56646526700 (19, Mira St., Ekaterinburg, 620002, Russian Federation; e-mail: 1.s.ruzhanskaya@urfu.ru).

Sergey Aleksandrovich Lukyanov - Doctor of Economics, Professor; Head of Department, Department of Economic Theory, State University of Management; Graduate School of Economics and Management, Ural Federal University; Professor, Department of World Economy, Faculty of Economics, Saint Petersburg State University; orcid.org/0000-0002-0736-1533 (99, Ryazansky Ave., Moscow, 109542; 19, Mira St., Ekaterinburg, 620002; 7-9, Universitetskaya Emb, St. Petersburg, 199034, Russian Federation; e-mail: s.lukyanov@mail.ru).

Georgy Andrevich Alaev - PhD Student, Graduate School of Economics and Management, Ural Federal University, (19, Mira St., Ekaterinburg, 620002, Russian Federation; e-mail: georgy.alaev@yahoo.com). 